\title{
Post-release ranging behaviour of hand-raised black rhinoceros, Diceros bicornis, L. in Matusadona National Park, Zimbabwe with recommen- dations for management of introduction to the wild
}

\author{
G. Matipano
}

Matipano, G. 2004. Post-release ranging behaviour of hand-raised black rhinoceros, Diceros bicornis, L. in Matusadona National Park, Zimbabwe with recommendations for management of introduction to the wild. Koedoe 47(1): 89-101. Pretoria. ISSN 0075-6458.

\begin{abstract}
Hand-raised rhinos would preferentially settle at sites close to areas where human activity was significant. Hand-raised rhinos that attached themselves to sites of human activity tended to move less widely and to have smaller seasonal ranges than those that moved away from human settlements. These rhinos had no fear of humans and some animals would move along established roads into hostile areas outside the park. These factors made hand-raised rhinos more vulnerable to poaching than their wild counterparts. Management of hand-raised rhinos with regards to ranging behaviour is discussed in the text.
\end{abstract}

Key words: black rhino, hand-raised, ranging behaviour, reintroduction.

G. Matipano, Matusadona National Park, Parks and Wildlife Management Authority, Private Bag 2003, Kariba, Zimbabwe. Present address: National University of Science and Technology, Department of Forest Resources and Wildlife Management, P. O. Box AC 939, Ascot, Bulawayo, Zimbabwe (gmatipano@nust.ac.zw).

\section{Introduction}

Reintroduction is an important wildlife management technique for conservation of endangered species including the black rhinoceros. The first months after release in a new area are naturally a stressful period for introduced rhino (Adcock et al. 1998). Wild black rhino are known to be a relatively poor dispersing species after introduction to a new area. Reintroduction of black rhino met with problems, including poor habitat quality and hence poor reproductive performance (Emslie 1994). Other problems are related to mass release of animals at one site at the same time and the resultant mortality due to intra-specific fights among introduced animals (Emslie 1994) and intra-specific aggression from resident individuals (Brett 1998).

This paper focused on seasonal ranges rather than home ranges. This was done because some of the hand-raised rhinos were too young to hold home ranges. Others, although they were adults on release, had not had enough time to established home ranges by the time of the study. Home range is that area traversed by an individual animal in its normal activities of food gathering, mating and caring for young excluding the area outside its normal area (Burt 1943). Many factors influence the size of home ranges of black rhino. Home range areas vary with an animal's requirements: ranges tend to be larger when food, water and cover are scarce or scattered (Mukinya 1973). Black rhinos have larger home ranges in woodlands than in thickets (Hitchins 1969). Home ranges tend to increase in area with decreasing browse availability. The social status (group member, loner, resident, transient), age, sex and reproductive condition may influence range sizes (Bekoff \& Mech 1984). Generally, adult male rhinos tend to have smaller home ranges than adult females (OwenSmith 1988), but in some cases they are equal (Mukinya 1973). Ranges of immature black rhinos and females with calves are larger than those of single adult males or females (Joubert \& Eloff 1971). For cows, 
this difference may be due to the need to meet food requirements and to acquaint the calf with the home range (Mukinya 1973). Typical black rhino mean home range sizes are 7-35 km² (Owen-Smith 1988).

Animals do not use home ranges in a uniform manner. Core areas denote space of high home range usage. An animal can have one or more core areas in its home range (Dixon \& Chapman 1980). Core areas may provide a more clear measure of the changing pattern of range use than home range area (Harris et al. 1990). In general, core areas of conspecific animals are mutually exclusive (Harris et al. 1990) but can overlap for rhinos, specifically (Tatman et al. 2000).

Ranging behaviour studies of black rhinos have been carried out on wild free-ranging populations (e.g. Goddard 1967; Mukinya 1973; Frame 1980; Kiwia 1989), and on relocated or reintroduced populations (e.g. Hitchins 1969; Adcock et al. 1998; Tatman et al. 2000). However, information on the ranging behaviour of hand-raised and released black rhinos is scarce and is not directly related to Matusadona National Park (MNP). Objectives of the study are to determine effects of hand-raising on the ranging behaviour of black rhinos, and secondly to contribute information towards the development of guidelines for sound reintroduction process and post-release management of hand-raised black rhino.

\section{Methods}

\section{Study area}

Matusadona National Park (MNP) stretches from $28^{\circ} 23^{\prime} \mathrm{E}-28^{\circ} 51^{\prime} \mathrm{E}$ and from $16^{\circ} 41^{\prime} \mathrm{S}-17^{\circ} 13^{\prime} \mathrm{S}$. The park is about $1407 \mathrm{~km}^{2}$ in area. An escarpment divides the park into two major geomorphologic landscapes, the semi-arid eutrophic Valley Floor lying between $485 \mathrm{~m}$ and $600 \mathrm{~m}$ above sea level (a.s.1.) and the wet dystrophic highland section lying between $600 \mathrm{~m}$ and $1200 \mathrm{~m}$ a.s.l. The lowland area is dominated by semi-arid vegetation mainly Colophospermum mopane (Kirk ex Benth.) Kirk ex J. Léonard woodland while the highland area supports Brachystegia Benth.-Julbernadia Pellegr. woodlands. The study was restricted to the Valley Floor section of the park. MNP has a semi-arid climate in the Valley Floor where rainfall ranges between 400 and $800 \mathrm{~mm}$ per year with an average mean annual of $729.5 \mathrm{~mm}$.

\section{Study rhinos}

No rhinos were collared specifically for this project. Two adult female rhinos were collared in 1998. Four hand-raised rhinos (two adults: male and female, and two subadults: male and female) also had been radiocollared before the research project started. Sex, origin, duration stayed in bomas, season of release, age on release and age during the time of study of the hand-raised rhinos are shown in Table 1. The ages of rhinos during the time of the study ranged between 4.5 and 13 years. These animals had been kept in bomas for 4-12 years before final release. Handraised animals were first released into MNP in March 1998. During the study the park was supporting about 55 black rhinos (wild, hand-raised and released and those that were still under hand-raising).

Collared animals were radio-tracked by telemetry and their positions were recorded using a GPS between March 1998 and July 2000. Routine monitoring data (Department of National Parks and Wildlife Management files) on two wild adult female rhinos were used to calculate seasonal range sizes for 1998.

During fieldwork, the target was to locate each collared animal at least once a week, using a Telonics Model TR-2 receiver. Radio-collared animals were initially approached by vehicle, and final contact was made on foot to avoid disturbance. An animal's position on first sighting was recorded using a GPS Garmin 40. Data collection was limited to diurnal observations. Information was collated by season, as follows: wet season (December-March), early dry season (May-July) and late dry season (Septemberearly November).

\section{Calculation of seasonal range sizes}

The vegetation map of MNP compiled by Taylor (1985) was scanned and digitised into the TNTMIPS GIS software programme operated by the WWF Multispecies Project. Positions of individual rhinos were plotted on the vegetation map. The $100 \%$ Minimum Convex Polygon (Mohr 1947) was used to draw seasonal ranges and to calculate their sizes. In this study, seasonal range was investigated in the wet, early dry and late dry seasons.

The $100 \%$ MCP method was chosen for its ease of use. Radio-locations were assumed to be non-auto- 
Table 1

History of hand-raised rhino in MNP

\begin{tabular}{lllcccc}
\hline $\begin{array}{l}\text { Name of } \\
\text { rhino }\end{array}$ & Sex & Source & $\begin{array}{c}\text { Duration } \\
\text { in boma } \\
\text { (years) }\end{array}$ & $\begin{array}{c}\text { Age on } \\
\text { release } \\
\text { (years) }\end{array}$ & $\begin{array}{c}\text { Season of } \\
\text { final } \\
\text { release }\end{array}$ & $\begin{array}{c}\text { Date } \\
\text { of release }\end{array}$ \\
\hline Pfumbe & Male & $\begin{array}{l}\text { Mana Pools } \\
\text { via Imire }\end{array}$ & 12 & 12 & Early Dry & April 1999 \\
Cuckoo & Female & $\begin{array}{l}\text { Mana Pools } \\
\text { via Imire }\end{array}$ & 11 & 11 & Dry & June 1998 \\
$\begin{array}{l}\text { Chewore } \\
\text { Mgofu }\end{array}$ & $\begin{array}{l}\text { Female } \\
\text { Chewore }\end{array}$ & 5 & 5 & Wet & March 1998 \\
\hline
\end{tabular}

correlated because they were collected at least daily for a given rhino. Auto-correlation refers to two or more fixes that are not independent in terms of time. The MCP method, is not affected by temporal autocorrelation of fixes (Harris et al. 1990; Dexter 1999). This study only required an index of seasonal range, and not absolute sizes. The MCP is the smallest convex polygon containing all the observed positions; the area within this polygon is the estimated seasonal range size (Anderson 1982). Landscapes not known to be used by rhinos, such as water bodies, were excluded from the seasonal range area.

\section{Calculation of core area sizes}

The $70 \%$ Harmonic method (Dixon \& Chapman 1980) was used to calculate core areas for individual seasonal ranges. The relationships between seasonal range and core area sizes for both rhino groups were graphically presented.

\section{Statistical treatments}

The sample size was small and data were therefore pooled for analysis. The Chi-square tests were used to analyse the differences between mean seasonal range and core area sizes for hand-raised and wild rhinos. The same tests were used to analyse the within-group variation in seasonal range and core area sizes. The regression analysis was used to determine the relationship between seasonal range and core area sizes.

\section{Results}

\section{Movements of hand-raised rhinos}

No rhino settled at its release site. The longest period of monitoring (March 1998 -
July 2000) by radio tracking was for Chewore, a subadult female rhino. The animal was immobilised, translocated and released at Mhukadzapera River (Fig. 1) on the same day in March, 1998. It first left the park in November 1999, into the Nyaminyami district communal lands, about two years after release (Fig. 2). The animal was recaptured and released at Nyamoni River. Thereafter, Chewore repeatedly moved out (once in each of the months January, April, May, June, and July 2000), not only out of the study area itself but also out of the park. The longest distance moved from the park was about $40 \mathrm{~km}$, and from the study area was about $70 \mathrm{~km}$. Each time the animal moved out of the park, it walked along established roads. In communal lands, the animal tended to reduce movements. The animal used the same general route going out of the park and passing close to or through a township. At one time the rhino was put in an enclosure at a growth point township outside the park, awaiting collection by National Parks. Every time it was out of the park, the animal was walked back into the conservation area. This habit of hand-raised rhinos, of following roads, was also observed in the Midlands area of Zimbabwe (pers. obs.). Chewore was relocated to Sinamatella (Hwange National Park) in January 2002. Soon after arrival it crossed to Botswana from where it was later taken back.

Cuckoo, an adult female, was released by walking it out of the Gubu bomas (Fig. 3) in the early dry season, June 1998. The animal moved widely soon after release and in the 


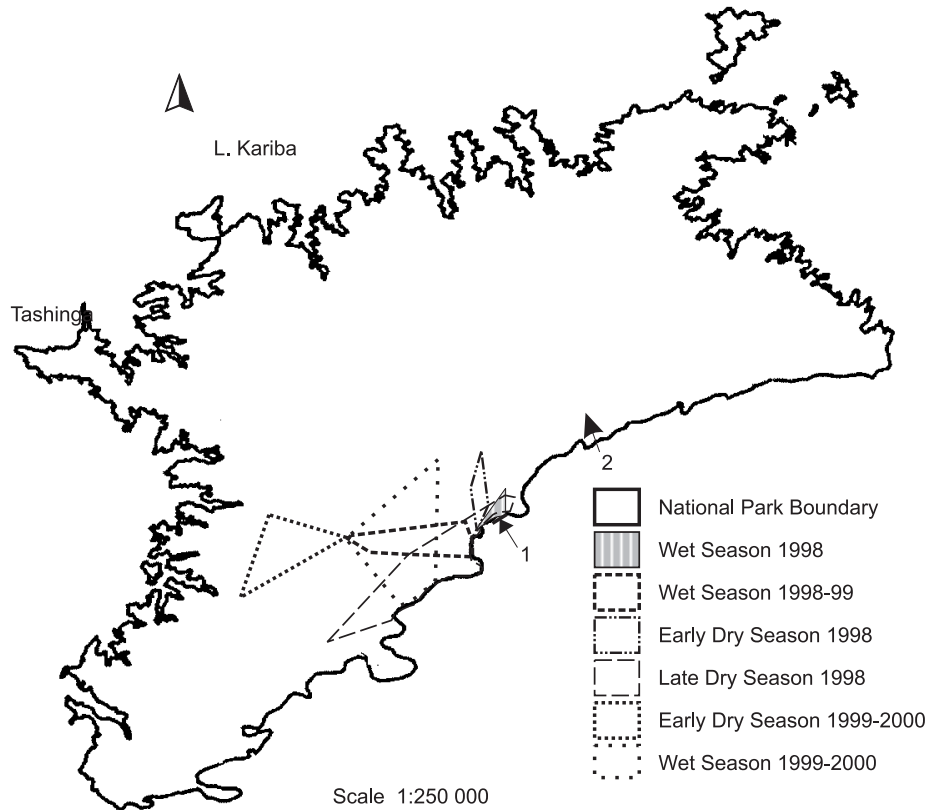

Fig. 1. Map of Matusadona National Park (MNP) showing seasonal ranges of a hand-raised rhino, 'Chewore'. 1. First release site (Mhukadzapera River) 2. Second release site (Nyamoni River).

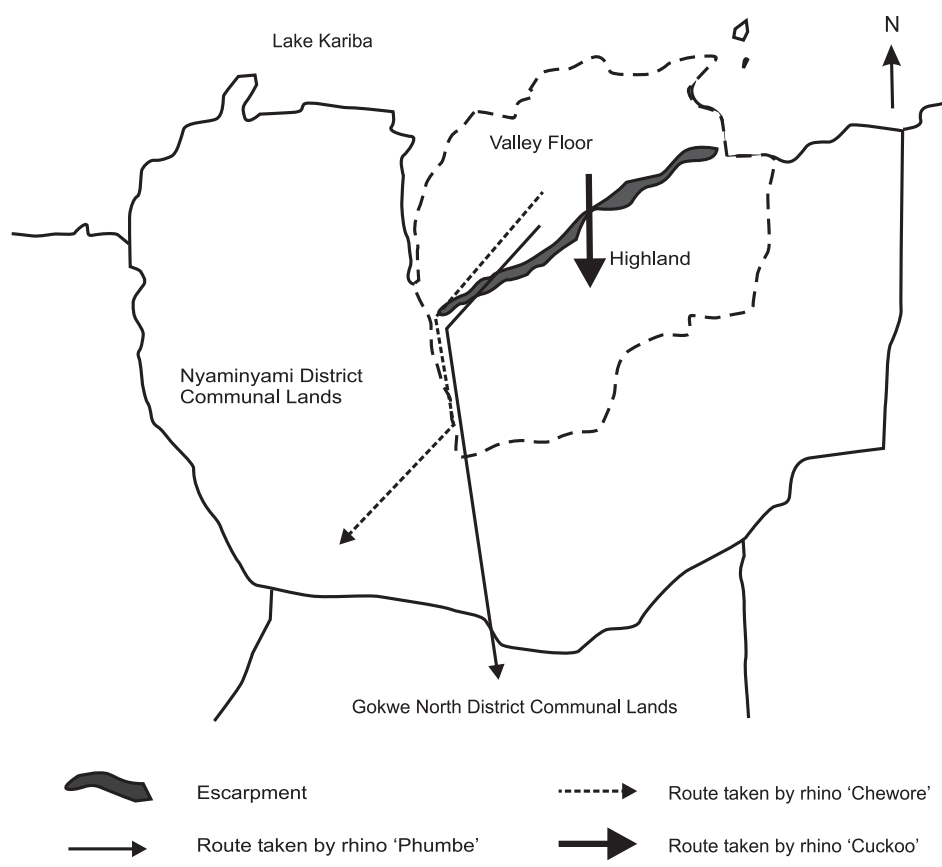

Fig. 2. Map showing movements of hand-raised rhino outside Matusadona National Park. 


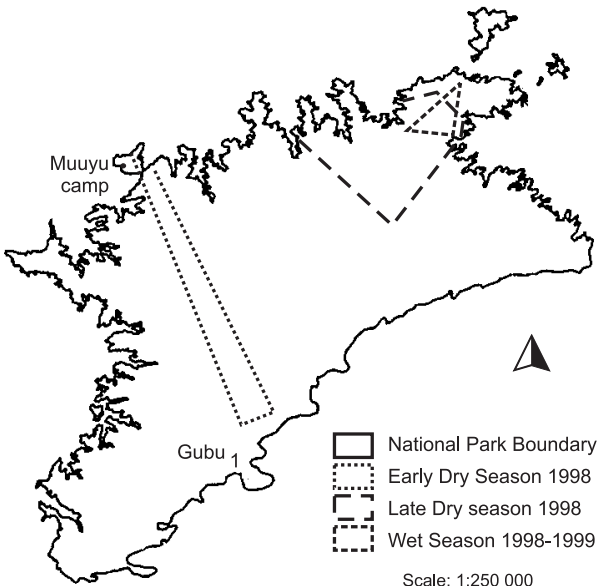

Fig. 3. Map of MNP indicating seasonal ranges of a hand raised rhino,'Cuckoo'. 1 = Release site.

subsequent late dry season. In the 1998/99 wet season, the animal then stayed briefly close to Muuyu and Changachirere camps on the lakeshore (where there was marked tourist activity). Later, she went up the escarpment, in the following early dry season, leaving the study area (Fig. 2).

An introduced adult male, Pfumbe, was released by walking it out from Gubu bomas in June 1998 (Fig. 4). The animal stayed briefly in the park and then crossed the park boundary into the Nyaminyami and Gokwe North District Communal Lands (Fig. 2). In communal lands the animal did not to move widely and could visit homesteads. Once the animal broke window panes at a villager's homestead. After staying for about two weeks in the communal lands, Pfumbe was recaptured and placed in the boma at Tashinga Camp in July 1998. The animal was released again in January 1999 from the Tashinga bomas by letting it walk out on its own. After engaging in two serious fights with a wild resident bull, Pfumbe returned into the boma of its own accord. Pfumbe was immobilised and transported and finally released at lower Jenje River, in April 1999 (Fig. 4). By May 2003, the animal seemed to

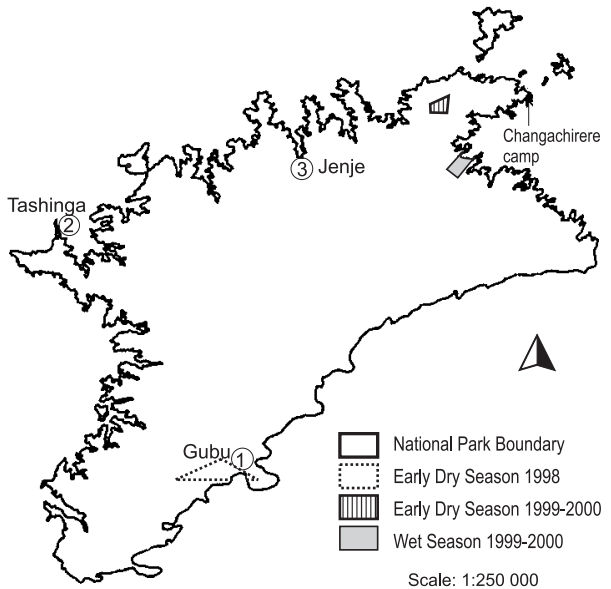

Fig. 4. Map of MNP indicating seasonal ranges of a hand-raised rhino, 'Pfumbe'. 1-3 = Release sites 1-3.

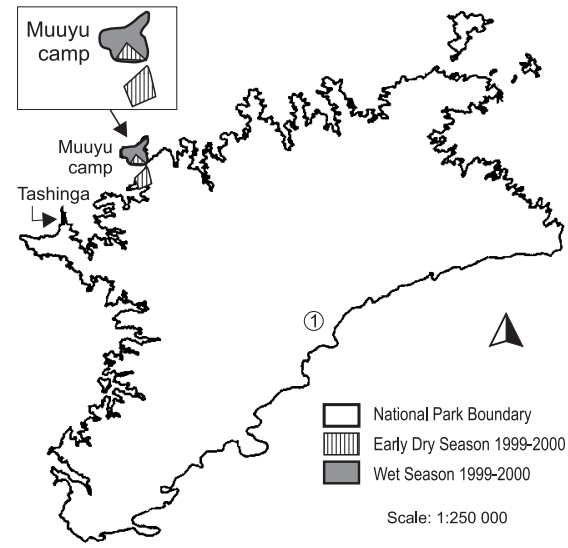

Fig. 5. Map of MNP indicating seasonal ranges of a hand-raised rhino, 'Mgofu'. 1 = Release site.

have settled near Changachirere Camp where it settled since 2000 .

Mgofu was walked to a satellite boma at upper Jenje River (Site 1), about $18 \mathrm{~km}$ from the raising boma at Tashinga. It stayed there for about one and half months before final release into the wild in December 1999. The animal moved for about $12 \mathrm{~km}$ to a headland in the Lake Kariba, where Muuyu camp is 


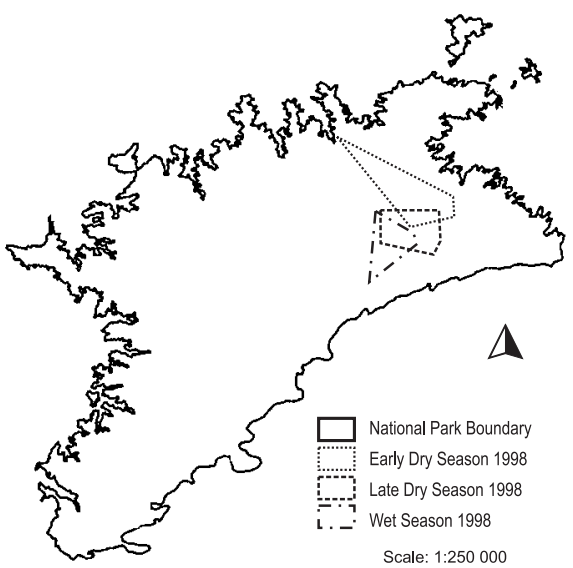

Fig. 6. Map of MNP indicating seasonal ranges of a female wild rhino number 7 .

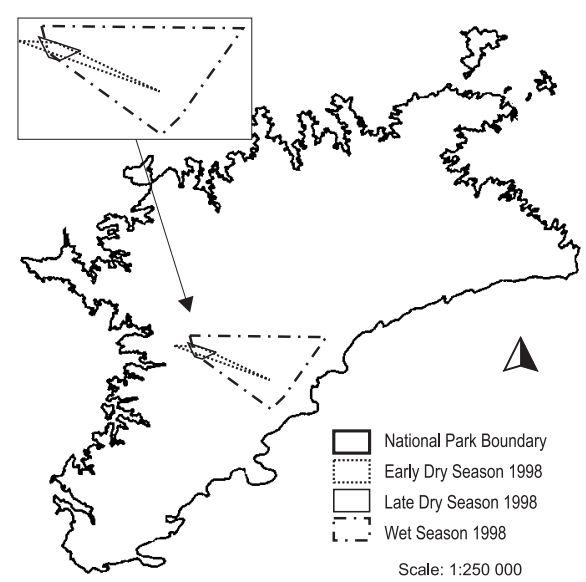

Fig. 7. Map of MNP indicating seasonal ranges of a wild female rhino number 21 .

Table 2

Seasonal ranges and core areas of black rhinos in MNP

\begin{tabular}{|c|c|c|c|c|c|c|c|}
\hline $\begin{array}{l}\text { Year and } \\
\text { season }\end{array}$ & $\begin{array}{l}\text { Rhino } \\
\text { group }\end{array}$ & $\begin{array}{c}\text { Rhino } \\
\text { identity } \\
\text { (no./name) }\end{array}$ & $\begin{array}{l}\text { No. of } \\
\text { fixes } \\
\text { used }\end{array}$ & $\begin{array}{l}\text { Seasonal } \\
\text { range } \\
\text { size }\left(\mathrm{km}^{2}\right)\end{array}$ & $\begin{array}{c}\text { bMean } \\
\text { seasonal range } \\
\text { size }\left(\mathrm{km}^{2}\right)\end{array}$ & $\begin{array}{c}\text { Core } \\
\text { area size } \\
\left(\mathrm{km}^{2}\right)\end{array}$ & $\begin{array}{l}\text { Mean core } \\
\text { area size } \\
\left(\mathrm{km}^{2}\right)\end{array}$ \\
\hline \multirow{3}{*}{$\begin{array}{l}1998 \text { wet } \\
\text { season }\end{array}$} & Wild & 7 & 5 & 20.8 & & 7.3 & \\
\hline & & 21 & 6 & 32.9 & 26.9 & 14.1 & 10.7 \\
\hline & Hand-raised & Chewore & 6 & 0.8 & 0.8 & 0.2 & 0.2 \\
\hline \multirow{5}{*}{$\begin{array}{l}1998 \text { early } \\
\text { dry season }\end{array}$} & Wild & 7 & 5 & 10.4 & & 0.8 & \\
\hline & & 21 & 4 & 2.1 & 6.3 & 1.9 & 1.4 \\
\hline & Hand-raised & Chewore & 8 & 2.3 & & 2.3 & \\
\hline & & Cuckoo & 4 & 32.6 & & 11.2 & \\
\hline & & Pfumbe & 4 & 4 & 13.0 & 1.2 & 4.9 \\
\hline \multirow{4}{*}{$\begin{array}{l}1998 \text { late } \\
\text { dry season }\end{array}$} & Wild & 7 & 6 & 13.7 & & 0.6 & \\
\hline & & 21 & 6 & 1.3 & 7.5 & 0.4 & 0.5 \\
\hline & Hand-raised & Chewore & 8 & 15.6 & & 6.4 & \\
\hline & & Cuckoo & 7 & 58.7 & 37.2 & 55.5 & 31.0 \\
\hline \multirow{2}{*}{$\begin{array}{l}1998 / 99 \\
\text { wet season }\end{array}$} & Hand-raised & Chewore & 4 & 7.3 & & 0.6 & \\
\hline & & Cuckoo & 6 & 7.5 & 7.4 & 0.6 & 0.6 \\
\hline \multirow{3}{*}{$\begin{array}{l}1999 / 2000 \\
\text { wet season }\end{array}$} & Hand-raised & Chewore & 8 & 22 & & 1.5 & \\
\hline & & Pfumbe & 6 & 1.3 & & 0.6 & \\
\hline & & Mgofu & a & 1.5 & 8.0 & $\mathrm{a}$ & 1.4 \\
\hline \multirow{3}{*}{$\begin{array}{l}2000 \text { early } \\
\text { dry season }\end{array}$} & Hand-raised & Chewore & 6 & 9.8 & & 1.5 & \\
\hline & & Pfumbe & 8 & 1.2 & & 0.2 & \\
\hline & & Mgofu & 7 & 1.2 & 4.1 & 1 & 0.9 \\
\hline
\end{tabular}

a Area was estimated based on the island the animal was occupying in that season

b Mean seasonal range sizes (column six) are not for individual rhinos but for a group of rhinos, i.e. wild and hand-raised rhino groups. 
Table 3

Chi-square tests on the differences in seasonal range and core area sizes within hand-raised and wild rhino groups

\begin{tabular}{|c|c|c|c|c|}
\hline Year and season & Rhino group & $\begin{array}{l}\text { Rhino name or } \\
\text { number }\end{array}$ & $\begin{array}{l}\text { Significant }(\mathrm{S}) \text { or } \\
\text { not significant }(\mathrm{Ns}) \\
\text { seasonal range }\end{array}$ & Core area \\
\hline \multirow[t]{2}{*}{1998 wet season } & Wild & $7 \times 21$ & Ns & Ns \\
\hline & Wild & $7 \times 21$ & $\mathrm{~S}$ & Ns \\
\hline \multirow[t]{3}{*}{1998 early dry season } & Hand-raised & Chewore x Cuckoo & $\mathrm{S}$ & $\mathrm{S}$ \\
\hline & & Chewore $x$ Pfumbe & Ns & Ns \\
\hline & & Cuckoo x Pfumbe & $\mathrm{S}$ & $\mathrm{S}$ \\
\hline \multirow[t]{2}{*}{1998 late dry season } & Wild & $7 \times 21$ & $\mathrm{~S}$ & Ns \\
\hline & Hand-raised & Chewore x Cuckoo & $\mathrm{S}$ & $\mathrm{S}$ \\
\hline \multirow[t]{2}{*}{ 1998-99 wet season } & & Chewore x Cuckoo & $\mathrm{S}$ & Ns \\
\hline & & Chewore $x$ Pfumbe & $\mathrm{S}$ & Ns \\
\hline \multirow[t]{3}{*}{$99 / 2000$ wet season } & Hand-raised & Chewore x Mgofu & $\mathrm{S}$ & Ns \\
\hline & & Pfumbe x Mgofu & Ns & Ns \\
\hline & & Chewore $x$ Pfumbe & $\mathrm{S}$ & Ns \\
\hline \multirow[t]{2}{*}{2000 early dry season } & Hand-raised & Chewore x Mgofu & $\mathrm{S}$ & Ns \\
\hline & & Pfumbe x Mgofu & Ns & Ns \\
\hline
\end{tabular}

situated (Fig. 5). When the headland became an island, Mgofu moved to the mainland in the early dry season. By May 2003, the animal remained in the same area it had settled in previously, in 1999.

Figures $6 \& 7$ show movements of two wild adult females during the time of the study.

\section{Seasonal ranges' sizes}

Seasonal ranges of rhino groups are shown in Table 2. The mean seasonal range areas were significantly different from each other between hand-raised and wild rhinos in the wet and late dry seasons $\left(\chi^{2}>19 ; p<0.001\right)$ and not in the early dry season $\left(\chi^{2}=2.350\right.$; $0.1<p<0.25$, Table 3 ) in 1998. In the wet season the mean seasonal range area for handraised rhinos was smaller than that for wild rhinos and the situation was vice versa in the dry seasons in 1998. Between 1999 and 2000 , the mean seasonal range areas for hand-raised rhinos varied with season and ranged between $4.1 \mathrm{~km}^{2}$ and $8.0 \mathrm{~km}^{2}$.
The within-group seasonal range variation in size was significant for hand-raised rhino $\left(\chi^{2}>5 ; p<0.025\right)$, except between Chewore and Pfumbe in the 1998 early dry season, and Pfumbe and Mgofu in the 2000 wet and early dry seasons $\left(\chi^{2}<2.727 ; p>0.1\right.$; Table 3). Pfumbe and Mgofu had the smallest seasonal ranges, as these animals had settled close to human settlements.

Seasonal ranges of hand-raised rhinos that settled close to human activity were both smaller than those of hand-raised rhinos that settled further away from man, and than those of their wild counterparts (Table 2). Seasonal ranges of rhinos were variable in terms of spatial location with season (Figs. 1 \& 3-7). There was some overlap in seasonal ranges of a given individual animal except Pfumbe.

\section{Core area sizes}

The mean core areas for both hand-raised and two wild rhinos are shown in Table 2 . 
The mean core area sizes for hand-raised and wild rhinos were significantly different from each other in the wet and late dry seasons $\left(\chi^{2}>10 ; p<0.05\right)$ and not significantly different in the early dry season $\left(\chi^{2}=2.016\right.$; $0.1<p<0.25)$ in 1998 . In the wet season, the mean core area for hand-raised rhinos was smaller than that for the wild group, and the situation was vice versa in the dry season.

In 1998, the within-group variations in core area size of hand-raised rhino were not significantly different $\left(\chi^{2}<2.166 ; p>0.1\right)-$ except between Chewore and Cuckoo and Pfumbe and Cuckoo in the early dry season, and Chewore and Cuckoo in the late dry season $\left(\chi^{2}>8.066 ; p<0.05\right.$; Table 3$)$. Cuckoo appeared to move widely and to be responsible for the major variations in seasonal ranges of hand-raised rhinos.

\section{The relationships between seasonal range and core area sizes}

The relationships between seasonal range and core area sizes are shown in Fig. 8. The sizes of core areas increased significantly with the increasing seasonal range areas for both rhino groups $\left(r^{2}>0.67 ; p<0.03\right)$.

The relationships between seasonal range and core area sizes were represented by the following equations for wild rhinos (I) and hand-raised rhinos (II):

Seasonal range area $=-1.35+0.394 x$ core area size ........................(I)

Seasonal range area $=-3.87+0.81 \times$ core area size ...................... (II)

There was a threshold below which the decrease in seasonal range sizes did not result in significant decrease in core area sizes $\left(r^{2}=0.0 ; p>0.63\right)$. The threshold was lower for hand-raised than for wild rhino rhinos, i.e., $15.6 \mathrm{~km}^{2}$ and $20.8 \mathrm{~km}^{2}$, respectively. Below the threshold, core area size remained below $2.4 \mathrm{~km}^{2}$ for hand-raised rhinos, and below $2 \mathrm{~km}^{2}$ for wild rhinos and they were not significantly different from each other $\left(\chi^{2}=0.036, p>0.75\right)$.

\section{Discussion}

The study did not focus on the concept of home range, but on seasonal range, because of reasons discussed in the introduction and below. Analysis of seasonal ranges was appropriate because short-term seasonal ranges are necessary for studying dispersing animals and when monitoring change in range use over time (Harris et al. 1990). Analyses at the level of the annual range under-utilise available data and do not show the within-year variations. Thus, seasonal ranges can yield additional information compared to annual ranges.

Problems common to use of seasonal and annual ranges include that of distinguishing abnormal from normal movements of the animal. Animal locations outside the study area were disregarded in the analysis. Seasonal ranges have potential for additional errors compared to annual ranges. Seasonal range shift is a series of continuous changes in location and time. It is represented by a series of overlapping ranges. That period of shifting from one seasonal range to another might not be identifiable on the ground. The researcher defined the time frame for seasonal ranges. The defined time frame for seasonal ranges might not be biologically meaningful to the species, i.e., the season of the range that has been determined by the researcher might not coincide with that for the animal.

A trial run of the experiment should have been carried out to establish the time interval to collect data such that serial correlation of fixes does not occur. A test of independence of the fixes will reveal whether an animal is shifting its seasonal range or not. Serially correlated subsets of data may indicate the spatio-temporal transitional phase between seasonal ranges (Swihart \& Slade 1985). Major components of the behavioural ecology of the species should be considered to establish whether the shift in ranges is attributable to season or not.

It was difficult to find out whether handraised rhinos were moving within the seasonal ranges or were changing seasonal 


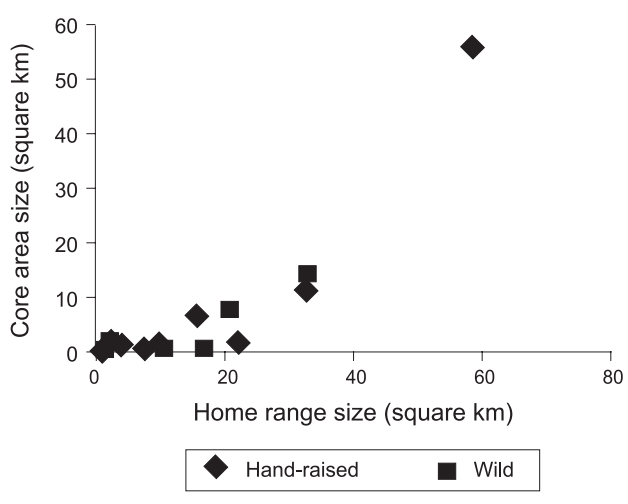

Fig. 8. The relationship between black rhino core area and home range sizes.

ranges or moving about without defined seasonal ranges. Seasonal ranges were highly variable both within and between groups of wild and hand-raised rhinos. The variation was in size and in location, according to season.

Wild rhinos less than eight years old are too young to hold home ranges (Adcock 1994). Half of the hand-raised rhinos, therefore, had not reached this critical age. In the wild, calves of both sexes sever relationship with their mothers at 2-4 years old and can move widely for up to another four years before establishing a home range (Adcock 1994). In areas with a high density of adult bulls, young males remain with their mothers for protection, up to the age of eight years (Adcock 1994). In Kenya and South Africa, wild captured rhinos (not hand-raised) had the highest mortality due to intra-specific fights within two years of release (Brett 1998) and could take up to three years to settle in terms of home range sizes (Adcock et al. 1998). It is, therefore, normal for rhinos to wander about soon after weaning or reintroduction into the wild. A matter of concern was the extent of movements by hand-raised rhinos, especially into potentially hostile areas, after reintroduction.

In the wild, black rhino are relatively solitary and sedentary, confining their normal movements to their home ranges (OwenSmith 1988). Movements of hand-raised rhinos were influenced by the presence of human settlements and, probably, by dominant wild bulls. Seasonal ranges were smaller for hand-raised rhinos that stayed close to human settlements than those that were further away. The mean seasonal range areas for hand-raised rhinos decreased with time after release as the animals were prevented from further northward movement by Lake Kariba waters and settled near tourist camps. Staying close to human settlements was a direct result of hand-raising on the behaviour of rhinos.

Rhinos released in the dry season moved widely soon after release compared to those that were released in the wet season. The wide movements might have been in response to low availability and poor interspersion of resources in the dry season compared to the wet season conditions. In reintroduction, animals should be released in the wet season or just after the rains when resources are still abundant.

For various reasons, sample sizes were too small to be meaningful for both within and between wild-release group comparisons. The problem could not be resolved by pooling data because the within-group variance led to pseudoreplication. The small sample size therefore did not allow for meaningful conclusions on the roles of social status (resident or transient), sex-age status, reproductive condition and even season in determining home range size (Bekoff \& Mech 1984). Further, it was not possible to assess how the following variables affected seasonal range sizes: the period the animal had spent in the wild after release, the year or season of release, and the age of the rhino on release. An adult female rhino, Cuckoo was responsible for the variation in core area within the hand-raised group.

The number of fixes used for each rhino was not adequate for seasonal range analysis and could have resulted in bias by under-estimating range sizes. The MCP method is sensitive to sample size. Home range sizes 
increase as the number of fixes increase towards the asymptote (Bekoff \& Mech 1984), and the asymptotic level is reached when a further addition of fixes does not result in increase in the size of the home range. In this study (Table 2), seasonal ranges for hand-raised rhino fell in the lower range of wild counter-parts in comparable semi-arid areas of Africa-including MasaiMara in Kenya (Mukinya 1973) and Hluhluwe in South Africa (Hitchins 1971) - probably due to small numbers of fixes that were used and fixes recorded outside the study area were not used in the analysis. The number of fixes used for seasonal ranges were not the same for all rhinos, which prevented comparison of range attributes. As long as the number of fixes achieve asymptote, attributes whose range have been obtained using unequal number of locations can be compared.

Many researchers (e.g. Bekoff \& Mech 1984; Robertson et al. 1998), recommended a total of 100-200 fixes for large mammals in home range analysis. In Kenya, Tatman et al. (2000) found that 20 to 30 fixes were adequate for home range in a small and confined black rhino population. These extremes in the number of required fixes arise from different situations, where the large figure is for free-ranging population and the smaller for those small fenced ranches. Individual animals reach asymptotic number of fixes at different values, and some animals may not even reach an asymptote. For example, transient adults or dispersing subadult may not attain asymptote values (Harris et al. 1990). An inappropriate interval in collecting data may also govern failure to achieve asymptote (Harris et al. 1990). All hand-raised rhinos dispersed after release, which meant that the constantly changing localities did not always allow for asymptotic fixes.

The $100 \%$ MCP method, as an index to measure the ranging behaviour of rhinos, showed that hand-raised and wild rhinos were different from each other. The method includes portions of the study area that were not normally used by the animals. This results in overestimating the seasonal range size. The method, therefore, is biologically not suitable to study range sizes and habitat requirements unless it has been smoothed to correct for the increase in range size (White \& Garrott 1990; Conybeare 1991). Smoothing involves removal of outliers, i.e., those points which stand alone. The $70 \%$ harmonic mean method removed some of the outliers. Although smoothing drastically reduced the within-group variations, the mean core areas of hand-raised and wild rhinos became more significantly different from each other than their mean seasonal range areas. Hand-raised rhinos had a lower threshold than wild animals, below which the decrease in seasonal range areas did not result in significant decrease in core area sizes. On the other hand, the size of the core area below the threshold point was larger for hand-raised rhinos than for wild rhinos, though not significantly different from each other. These statements seemed to indicate that hand-raised rhinos tended to wander about until they establish a seasonal range. Findings of this study partially tended to agree with Harris et al. (1990) that home ranges vary greatly during dispersal period of animals while core areas remain constant for both dispersing and non-dispersing animals.

\section{Conclusion}

The ranging behaviour for hand-raised rhinos seemed to be partly depended on whether there was a human near the release site. Hand-raised rhinos would preferentially settle at sites close to areas where human activity was significant. Further, seasonal ranges established in the vicinity of human settlements were smaller than for those established independent of settlements. In this study, there was no conclusive data to show that any of the hand-raised rhinos, including adults of over 10 years old, had stabilised their seasonal range sizes 2.5 years after release. In some cases, hand-raised rhinos used established roads when moving to new sites outside MNP. Physical barriers 
were important to prevent hand-raised rhinos from moving about widely.

An understanding of ranging behaviour is critical in managing hand-raised rhinos. Ranging behaviour and reaction to human presence have a bearing on the security of hand-raised rhinos. Having no fear of humans, hand-raised rhinos were vulnerable to poaching.

\section{Management issues and recommendations}

There is no guarantee that a rhino will remain at a release site. Hand-raised rhinos became attached to sites where they had been raised, and treated humans as surrogate mothers. Those rhinos that did not return to raising sites or to human settlements made extensive post-release movements. These wide movements could result in reduced survival and reproduction as animals either entered areas of potential conflict with humans, or were killed (Linell et al. 1997) by humans in communal lands.

The season of release for rhinos is critical. Rhinos that were released in the dry season tended to move more widely soon after release compared to those that were released in the wet season. Rhinos moved widely in the dry season immediately after release probably in search of water and food. Rhinos should be released during the wet season when the resources are abundant.

Both the season and area selected for release will govern resource availability. Animals released in unsuitable habitats will move widely looking for water, food and refuge.

In this study hand-raised rhino behaved in the opposite way to wild rhino which Mukinya (1973), found to move widely where there were humans. In this study, the presence of humans seemed to be a factor for hand-raised rhinos to remain in the release area and not to move widely. Animals that were released further from human settlement tended to reduce movements once they had found one. In reintroduction of rhinos, the aim is to reduce human influence and to allow animals to naturalise fast. Hand-raised rhinos released close to humans will remain used to people and will fail to adapt to local conditions quickly. On the other hand rhinos that stay close to humans tend to survive for longer periods of time than those that live in areas where poachers can operate with little chance of detection (Du Toit, pers. comm.). However, if animals are released away from humans, they will have a higher probability of moving out of the protected area into high-risk areas. In reintroduction programmes hand-raised rhinos should be released away from human settlements, provided there are barriers to movement into unprotected areas.

Whether released adjacent to human settlement or not, monitoring is important for postrelease management. The time hand-raised rhinos took to settle after release was not established, and hand-raised rhinos were still ranging widely two and a half years after release. On release, hand-raised rhinos should be marked to allow identification and monitoring of individual animals and record dispersal patterns. Monitoring of hand-raised rhinos should be continued for several years after release, until the animals have settled down.

Hand-raised rhinos are more vulnerable to poaching than their wild counterparts. For at least two and half years after release, handraised rhinos sometimes did not run away from trackers, and would advance to within a few metres of researchers. In due course, hand-raised rhinos will make a significant contribution to the black rhino population in MNP. Currently (October, 2000), the combined total number of hand-raised rhinos and those still in bomas makes up about $6 \%$ of the MNP black rhino population. If there is an outbreak of poaching, hand-raised rhinos will be the first to suffer. Having a motivated, well-trained and adequately equipped antipoaching personnel is an important conservation measure for rhinos.

Hand-raised rhinos were released when they were more than three years old; age at which their wild counter-parts are weaned and when they are not old enough to establish home ranges. At the time hand raised rhino were released the resident population density was 
below 0.25 animals $/ \mathrm{km}^{2}$. By the time this study was done there were no deaths of hand-raised rhino caused by intraspecific fights. Hand-raised rhinos should continued to be released when they are aged above three years especially in areas where the resident population is at a low density. It is to be expected that on weaning, animals will extend their ranges. The extent of ranging after weaning is important as rhinos might enter into hostile areas. The age at which hand-raised rhinos establish home ranges is not known. Hand-raised rhinos should be released before they are sexually mature and before they reach the age at which wild rhinos establish home ranges to give them time to learn about their environment. There is also need to determine the density of the resident population at which intraspecific fights would cause significant loss of hand-raised rhinos.

In this study, those rhinos that moved northwards were resident for some time in habitats next to the lake. The reason why most of the animals that went to the lakeshore stayed in habitats close to the lake is not clear. Reasons why hand-raised rhino were found on the lakeshore might include that the rhino were taking refuge from aggressive wild counterparts resident in the interior of the study area and or were attracted to sites of high human activity at tourist camps or house-boats in bays. Physical barriers, e.g., a strong perimeter fence can prevent extensive movements especially where the release area is small. It would be appropriate to release rhinos in areas large enough to meet ecological and social requirements of the animals. The exact size of the release area for handraised rhinos to meet ecological and social requirements depends on factors including habitat quality, density of the resident population, history of the animal and existence of the boundary game fence. Unfenced release areas for hand-raised rhinos should be at least $1000 \mathrm{~km}^{2}$. In unfenced areas, animals should be released at sites from where there is the greatest distance to the edge of the conservation area. For animals that have learnt how to repeatedly move out of a large release area, relocation to a totally new area might be a solution. Such rhinos should be relocated to fenced areas that offer animals better security.

Most of the Department of National Parks and Wildlife Management areas designated for release of rhinos are surrounded by communal lands. If rhinos move into communal lands there will be potential conflict with local communities. Nevertheless, some residents in the communal lands assist by reporting the presence of stray rhinos in their areas. An education programme is necessary to allow local communities to appreciate efforts to conserve endangered species. This includes the safari industry within and outside the park, as well as local residents in the surrounding communal lands. In the case of MNP, the adjacent Nyaminyami District is a designated Communal Area Management Programme For Indigenous Resources (CAMPFIRE) area with a Wildlife Section that can jointly work with MNP staff to carry out antipoaching and monitoring activities.

\section{Acknowledgements}

This article was produced as part of my MSC. Thesis. Financial support from the European Commission is greatly appreciated. I would like to thank my MSc project internal supervisor Dr. C. A. M. Attwell and external technical supervisor Mr. R. F. du Toit. I thank the Chief Ecologist (Terrestrial Ecology) Mr. E. Chidziya of the Department of National Parks and Wildlife Management for his support during the study. I am grateful to Matusadona staff, especially senior scout E. Muchuchutiti and scout $T$. Nyakashaya for their assistance during field work. Finally, I thank the Acting Director, Brigadier E. Kanhanga of the Department of National Parks and Wildlife Management for granting permission to carry out the study in Matusadona National Park.

\section{References}

ADCOCK, K. 1994. The relevance of territorial behaviour in black rhino to the population management. Pp. 82-86. In: Penzhorn, B.L. \& N.P. Kriek (eds.). Proceedings of a Symposium on Rhinoceros as Game Ranch Animals, Onderstepoort. September, 1994.

Adcock, K., H. Hansen \& H.J. Lindemann. 1998. Lesson from the introduced black rhino popula- 
tion in Pilanesberg National Park. Pachyderm 26: 40-68.

AEbischer, N.J., P.A. Robertson \& R.E. KenWARD. 1993. Compositional analysis of habitat use from animal radio-tracking data. Ecology 75(5): 1313-1325.

ANDERSON, D.J. 1982. The home range: a new nonparametric estimation technique. Ecology 63: 103-112.

ATKINSON, S.J. 1995 Maintenance of captive black rhinos (Diceros bicornis) on indigenous browse in Zimbabwe: energetics, nutrition and implications for conservation. MSc. thesis. University of Zimbabwe.

Bekoff, M. \& L.D. Mech. 1984. Simulation and analyses of space use: home range estimates, variability, and sample size. Behaviour Research Methods, Instruments, and Computers 16(1): 32-37.

BRETT, R. 1998. Mortality factors and breeding performance of translocated black rhinos in Kenya: 1984-1985. PACHYDERM 26:69-82.

BURT, W.H. 1943. Territoriality and home range concepts as applied to mammals. Journal of Mammalogy 24: 346-353.

Conybeare, A.M. 1991. Elephant occupancy and vegetation change in relation to artificial water points in a Kalahari sand area of Hwange National Park. PhD thesis. University of Zimbabwe, Harare.

DEXTER, N. 1999. The influence of pasture distribution, temperature and sex on home range sizes of feral pigs in a semi-arid environment. Wildlife Research 26: 755-762.

DiXON, K.R. \& J.A. CHAPMAN. 1980. Harmonic mean measure of animal activity areas. Ecology 61: 1040-1044.

FrAME, G.W. 1980. Black rhinoceros (Diceros bicornis L.) sub-populations on the Serengeti Plains, Tanzania. African Journal of Ecology 18: 155-166.

GoDDARD, J. 1967. Home range, behaviour and recruitment rates of two black rhinoceros populations. East African Wildlife Journal 5: 133-150.

Harris, S., W.J. Cresswell, P.G. Forde, W.J. Trewhella, T. WoOllard \& S. Wray. 1990. Home range analysis using radio-tracking data - a review of problems and techniques particularly applied in the study of mammals. Mammal Review 20 (2/3): 97-123.

Hitchins, P.M. 1969. The influence of vegetation types on the sizes of home ranges of black rhinos in Hluhluwe Game Reserve, Zululand. Lammergeyer 10: 81-85.

Hitchins, P.M. 1971. Preliminary findings of a radiotracking study on the black rhinoceros in
Hluhluwe Game Reserve, Zululand. A Symposium in Biometry, Pretoria. (Council for Scientific and Industrial Research, S57: 95-100).

Joubert, E. \& F.C. ElofF. 1971. Notes on the ecology and behaviour of the black rhinoceros, Diceros bicornis, L. 1758 in South West Africa. Madoqua Ser. 1(3): 5-53.

KIWIA, H.Y.D. 1989. Ranging patterns of the black rhinoceros (Diceros bicornis, (L)) in Ngorongoro Crater, Tanzania. African Journal of Ecology 27(4): 305-312.

Linell, J.D., R. AAnes, J.E. Swenson, J.OdDEN \& M.E. SMith. 1997. Translocation of carnivores as a method for managing problem animals: a review. Biodiversity and Conservation 6: 1245-1257.

Loutit, B.D., G.W. Louw \& M.K. SEely. 1987. Preliminary observation of food preferences and chemical composition of the diet of the desertdwelling black rhino. Madoqua 15: 35-54.

MoHR, C.O. 1947. Table of equivalent populations of North American small mammals. American Midlands Naturalist 37: 223-249.

Monro, R.H. 1982. An appraisal of some techniques to investigate the feeding ecology of large herbivores with reference to study of impala in the Northern Transvaal. African Journal of Ecology 20: 71-80.

MukINYA, J.G. 1973. Density, distribution, population structure and social organisation of the black rhino in Masai Mara Game Reserve. East African Wildlife Journal 11(3 \& 4): 385-400.

Owen-SMith, R.H. 1988. Megaherbivores. The influence of very large body size on ecology. Cambridge: Cambridge University Press.

Robertson, P.A., N.J. Aebischer, R.E. Kenward, I.K. HANSKI \& N.P. Williams. 1998. Simulation and jack-knifing assessment of home-range indices based on underlying trajectories. Journal of Applied Ecology 35(6): 928-940.

Smithers, R.H.N. \& V.J. Wilson. 1979. Checklist and Atlas of the mammals of Zimbabwe-Rhodesia. Museum Memoir 9: 1-147.

Swihart, R.K. \& N.A. Slade. 1985. Testing for independence of observations in animal movements. Ecology 66: 1176-1184.

Tatman, S.C., B. Stevens-Wood \& V.B.T. Smith. 2000. Ranging behaviour and habitat usage in black rhinoceros, Diceros bicornis, in a Kenyan sanctuary. Journal of African Ecology 38(2): 163-172.

Tufto, J., R. Andersen \& J. LinNell. 1996. Habitat use and ecological correlates of home size in a small cervid: the roe deer. Journal of Applied Ecology 65: 715-724. 